\title{
HUBUNGAN KEPUASAN KERJA DENGAN RETENSI STAF RUMAH SAKIT DI PROVINSI SULAWESI BARAT TAHUN 2017
}

\author{
Nadila Damayanti' ${ }^{1)}$, Fajar Ariyanti' ${ }^{2}$ \\ ${ }^{1,2}$ Program Studi Kesehatan Masyarakat, Fakultas Ilmu Kesehatan, UIN Syarif Hidayatullah \\ Jakarta \\ Email: fajar.ariyanti@uinjkt.ac.id
}

Diterima: Maret 2021, Diterbitkan: Juni 2021

\begin{abstract}
ABSTRAK
Kepuasan kerja dan retensi merupakan faktor penting dalam menentukan keberhasilan kinerja suatu organisasi dalam mencapai tujuannya, hal ini dikarenakan kepuasan kerja dan retensi dapat mempengaruhi kinerja seorang karyawan yang berperan penting dalam mencapai keberhasilan kinerja suatu organisasi. Penelitian ini bertujuan untuk mengetahui hubungan kepuasan kerja dengan retensi staf rumah sakit (medis dan non-medis) di Provinsi Sulawesi Barat Tahun 2017. Penelitian ini menggunakan desain penelitian cross sectional. Data pada penelitian ini menggunakan data sekunder Risnakes 2017 dengan sampel sebanyak 244 responden. Analisis data dilakukan dengan meggunakan uji Chi-square dengan CI 95\%. Hasil penelitian menunjukkan bahwa staf rumah sakit yang merasa puas sebesar 51,2\% dan staf rumah sakit yang berkeinginan untuk tetap bekerja sebesar 85,2\%. Hasil uji ChiSquare diperoleh nilai p-value sebesar 0,011 (p-value $<0,05)$ sehingga kesimpulan penelitian ini adalah kepuasan kerja berhubungan secara signifikan dengan retensi staf rumah sakit di Provinsi Sulawesi Barat Tahun 2017. Disarankan untuk seluruh rumah sakit di Provinsi Sulawesi Barat sebaiknya melakukan peningkatan terhadap manajemen SDM melalui peningkatan kegiatan monitoring dan evaluasi, dilakukannya peninjauan secara berkala pada faktor-faktor kepuasan kerja dan retensi, dan menjadikan penelitian-penelitian terkait sebagai referensi dalam menerapkan strategi peningkatan kepuasan kerja dan retensi.
\end{abstract}

Kata Kunci: Kepuasan Kerja, Retensi, Staf Rumah Sakit.

\section{ABSTRACT}

Job satisfaction and retention are important factors for in determining the success of an organization's performance ini achieving its goals, this is because job satisfaction and retention can affect the performance of an employee who plays an important role ini achieving the success of an organization's performance. This study aims to determine the relationship between job satisfaction and retention of hospital staff (medical and non-medical) in West Sulawesi Province in 2017. This study used a cross sectional research design. The data in this study used secondary data from Risnakes 2017 with a sample of 244 respondents. Data analysis was performed using the Chi-square test with 95\% CI. The results showed that the hospital staff who felt satisfied was $51.2 \%$ and the hospital staff who wanted to keep working were $85.2 \%$. The results of the Chi-Square test obtained a p-value of 0.011 (p-value $<0.05$ ) so that the conclusion of this study is that job satisfaction has a significant relationship with retention of hospital staff in West Sulawesi Province in 2017. It is recommended for all hospitals in the Province West Sulawesi should make improvements to human resource management through increased monitoring and evaluation activities, conducting regular reviews of job satisfaction and retention factors, and making related studies as references in implementing strategies for increasing job satisfaction and retention.

Keywords: Job Satisfaction, Retention, Hospital Staff.

\section{PENDAHULUAN}

Menurut Undang-Undang Republik Indonesia Nomor 44 Tahun 2009 tentang
Rumah Sakit, rumah sakit didefinisikan sebagai institusi pelayanan kesehatan yang menyelenggarakan pelayanan kesehatan perorangan secara paripurna yang 
menyediakan pelayanan rawat inap, rawat jalan, dan gawat darurat. Terciptanya pelayanan kesehatan yang berkualitas merupakan harapan bagi setiap masyarakat dan tujuan bagi yankes itu sendiri seperti rumah sakit. Dan dengan tersedianya peralatan yang berkualitas dan sumber daya manusia yang memadai di dalamnya dapat menjadi salah satu upaya untuk mencapainya (Prayoga dkk., 2017).

Menjadi sebuah kewajiban bagi rumah sakit sebagai institusi pelayanan kesehatan untuk mempunyai manajemen sumber daya manusia yang baik guna terciptanya pelayanan yang baik pula. Sumber daya manusia pada rumah sakit berperan sebagai kekuatan yang dapat menunjang kinerja rumah sakit dalam memberikan pelayanan kesehatan. Sebuah perusahaan mempunyai kelebihan yang berbeda-beda dimana pengelolaan sumber daya manusianya selalu diutamakan dalam berkompetisi dengan perusahaan lainnya. Oleh karena itu, sumber daya manusia termasuk dalam faktor penting bagi sebuah perusahaan atau organisasi pelayanan (Prayoga dkk., 2017).

Keberhasilan kinerja rumah sakit sangat dipengaruhi oleh kinerja karyawannya (Hilda dkk., 2014). Retensi karyawan sangat diperlukan untuk meningkatkan kinerja karyawan (Sumarni, 2011). Oleh karena itu, kinerja organisasi dalam mencapai tujuannya dapat dipengaruhi oleh tingkat retensi karyawan pada organisasi tersebut (Fatima, 2011).

Retensi karyawan merupakan keinginan atau niat karyawan untuk tetap bertahan pada suatu organisasi dalam jangka waktu yang lama (Susilo, 2013), sehingga organisasi perlu menstimulasi karyawan supaya bertahan pada perusahaan atau organisasi dalam jangka periode waktu yang telah ditentukan (Karthi \& Devi, 2012).

Keputusan karyawan dalam menentukan untuk tetap bertahan pada suatu organisasi tidak terlepas dari beberapa faktor yang mempengaruhinya yang dimana salah satunya adalah faktor kepuasan kerja
(Martoyo, 2007). Ketika karyawan merasa puas dengan pekerjannya maka niat yang dimiliki untuk keluar akan semakin rendah serta mereka akan lebih berkomitmen kepada perusahaan (Iqbal dkk., 2014). Dengan demikian, kepuasan kerja menjadi faktor penting dimana harus memiliki perhatian yang cukup serta harus terpenuhi pada karyawan (Aditeresna \& Mujiati, 2018).

Rumah sakit merupakan sebuah organisasi yang hasil pelayanannya dalam bentuk jasa, maka kualitas pelayanan terbaik kepada semua pasien rumah sakit harus diutamakan. Terwujudnya kualitas pelayanan yang baik juga tidak terlepas dari sikap puas karyawan dengan pekerjaannya (Novitasari, 2019). Kepuasan kerja merupakan perasaan postif pekerja terhadap pekerjaannya yang dimana merupakan hasil dari evaluasi karakteristiknya (Robbins \& Judge, 2011).

Penelitian yang dilakukan oleh Aprillia \& Mukti (2018), menunjukkan bahwasanya kepuasan kerja berpengaruh secara positif dan signifikan terhadap retensi karyawan. Dimana apabila terjadi peningkatan kepuasan kerja pada karyawan, maka terjadi peningkatan pula pada retensi karyawan. Setara dengan penelitian yang dilakukan oleh Lisdayanti (2015) yang juga menunjukkan bahwasanya kepuasan kerja berpengaruh positif dan signifikan terhadap retensi karyawan.

Berdasarkan hasil Risnakes 2017 didapatkan bahwa tingkat kepuasan kerja staf rumah sakit di Indonesia pada kategori rendah $(23,9 \%)$, kategori sedang $(50,0 \%)$, kategori tinggi $(26,1 \%)$. Provinsi Sulawesi Barat merupakan provinsi dengan tingkat persentase tertinggi kepuasan kerja staf rumah sakit pada kategori rendah yaitu sebesar 34,8\%. Oleh karena itu, kepuasan kerja staf rumah sakit di Provinsi Sulawesi Barat bisa dikatakan terendah dibandingkan dengan provinsi lainnya dan melampaui tingkat persentase kepuasan kerja staf rumah sakit di Indonesia pada kategori rendah yang 
sebesar 23,9\%. Selain itu juga, masa kerja lama pada staf rumah sakit di Provinsi Sulawesi Barat hanya sebesar 22,2\% (Badan Penelitian dan Pengembangan Kesehatan, 2017).

Rendahnya kepuasan kerja dan masa kerja lama staf rumah sakit di Provinsi Sulawesi Barat perlu menjadi perhatian demi perbaikan kinerja rumah sakit serta mencegah terjadinya dampak dari ketidakpuasan kerja itu sendiri dan rendahnya persentase masa kerja lama menandakan bahwa rendahnya tingkat retensi karyawan staf rumah sakit, dan implikasi dari rendahnya tingkat retensi karyawan adalah tingginya tingkat turnover staf rumah sakit. Oleh karena itu, penelitian ini bertujuan untuk mengetahui hubungan antara kepuasan kerja dengan retensi staf rumah sakit di Provinsi Sulawesi Barat Tahun 2017.

\section{METODE PENELITIAN}

Jenis penelitian ini merupakan kuantitatif dan menggunakan desain penelitian cross sectional. Data pada penelitian ini menggunakan data sekunder Risnakes tahun 2017. Pelaksanaan analisis data oleh peneliti pada bulan Juli 2020 dengan menggunakan data sekunder Risnakes tahun 2017 dan mengambil lokasi penelitian di Provinsi Sulawesi Barat.

Populasi dalam penelitian ini adalah staf rumah sakit di seluruh rumah sakit di Provinsi Sulawesi Barat. Adapun staf rumah sakit yang dimaksud menurut Risnakes 2017 terdiri dari beberapa profesi, yaitu: 1) Dokter spesialis; 2) Dokter; 3) Dokter gigi; 4) Bidan; 5) Perawat; 6) Tenaga Farmasi; 7) Kesehatan Masyarakat; 8) Kesehatan Lingkungan; 9) Tenaga Gizi; 10) Keterapian Fisik; 11) Keteknisan Medis; 12) Teknis bomedis; 13) Kesehatan Tradisional; dan 14) Non-Tenaga Kesehatan. Jumlah sampel pada penelitian ini sebanyak 244 responden yang diambil dari seluruh Rumah Sakit di
Provinsi Sulawesi Barat sejumlah 10 rumah sakit.

Penelitian ini menggunakan data sekunder 2017 dan instrument penelitian menggunakan kuesioner individu petugas rumah sakit Risnakes 2017. Data yang dikumpulkan dan dianalisis adalah data kepuasan kerja dan retensi staf rumah sakit. Pada data yang diperoleh dilakukan cleaning, record, dan analisis data untuk melihat hubungan antar kedua variabel (kepuasan kerja dan retensi). Analisis data penelitian ini dilakukan dengan menggunakan analisis univariat dan bivariat. Pada analisis bivariat meggunakan uji Chisquare dengan CI $95 \%$ serta derajat kemaknaan (nilai $\alpha$ ) sebesar 5\% atau 0,05 .

Pelaksanaan penelitian ini sendiri telah memperoleh persetujuan etik dari Komite Etik Penelitian Kesehatan Fakultas Ilmu Kesehatan UIN Syarif Hidayatullah Jakarta No.Un.01/F.10/KP.01.1/KE.SP/08.08.004/2 020 dan izin pengambilan data dari Badan Penelitian dan Pengembangan Kesehatan Kementerian Kesehatan RI sebagai perizinan penggunaan data sekunder Risnakes 2017. Selain itu, sebagai data yang digunakan dalam penelitian ini data Risnakes 2017 dalam pelaksanaan pengumpulan datanya juga telah memperoleh persetujuan etik dari Komisi Etik Penelitian Kesehatan Badan Litbang Kesehatan No.LB.02.01/2/KE.130/2017.

\section{HASIL PENELITIAN}

\section{Analisis Univariat}

Tabel 1. Distribusi Frekuensi Kepuasan Kerja Staf Rumah Sakit di Provinsi Sulawesi Barat Tahun 2017

\begin{tabular}{lcc}
\hline Kepuasan Kerja & $\mathbf{n}$ & $\mathbf{\%}$ \\
\hline Tidak puas & 119 & 48,8 \\
Puas & 125 & 51,2 \\
\hline Total & 244 & 100 \\
\hline
\end{tabular}


Tabel 1 menunjukkan bahwa proporsi staf rumah sakit yang merasa puas $(51,2 \%)$ lebih besar dibandingkan dengan staf rumah sakit yang merasa tidak puas $(48.8 \%)$.

Tabel 2. Distribusi Frekuensi Retensi Staf Rumah Sakit di Provinsi Sulawesi Barat Tahun 2017

\begin{tabular}{lcc}
\hline \multicolumn{1}{c}{ Retensi } & n & \% \\
\hline $\begin{array}{l}\text { Tidak ada keinginan } \\
\text { tetap bekerja }\end{array}$ & 36 & 14,8
\end{tabular}

\section{Analisis Bivariat}

Tabel 3. Hubungan Kepuasan Kerja dengan Retensi Staf Rumah Sakit di Provinsi Sulawesi Barat Tahun 2017

\begin{tabular}{|c|c|c|c|c|c|c|c|c|}
\hline \multirow{3}{*}{$\begin{array}{c}\text { Kepuasan } \\
\text { Kerja }\end{array}$} & \multicolumn{4}{|c|}{ Retensi Staf Rumah Sakit } & & & \multirow{3}{*}{$\begin{array}{c}\text { OR } \\
(95 \% \mathrm{CI})\end{array}$} & \multirow{3}{*}{ Pvalue } \\
\hline & \multicolumn{2}{|c|}{$\begin{array}{c}\text { Tidak ada } \\
\text { keinginan } \\
\text { untuk tetap } \\
\text { bekerja }\end{array}$} & \multicolumn{2}{|c|}{$\begin{array}{c}\text { Ada } \\
\text { keinginan } \\
\text { untuk tetap } \\
\text { bekerja }\end{array}$} & \multicolumn{2}{|c|}{ Total } & & \\
\hline & $\mathbf{n}$ & $\%$ & $n$ & $\%$ & $\mathrm{n}$ & $\%$ & & \\
\hline Tidak Puas & 25 & 21,0 & 94 & 79,0 & 119 & 100 & & \\
\hline Puas & 11 & 8,8 & 114 & 91,2 & 125 & 100 & 5 & 0,011 \\
\hline Total & 36 & 14,8 & 208 & 85,2 & 244 & 100 & & \\
\hline
\end{tabular}

Pada tabel 3 dapat diketahui bahwa staf rumah sakit yang merasa tidak puas dan tidak berkeinginan untuk tetap bekerja hanya sebanyak 25 dari 119 orang (21\%), sedangkan staf rumah sakit yang merasa puas dan tidak berkeinginan untuk tetap bekerja hanya 11 dari 125 orang $(8,8 \%)$, hasil uji probabilitas menunjukkan nilai 0,011 yang artinya apabila alpha $5 \%$ maka terdapat hubungan signifikan antara kepuasan kerja dengan retensi.

Selain itu diperoleh nilai OR sebesar 2,756 (CI 95\% 1,289-5,893), artinya staf rumah sakit yang merasa tidak puas memiliki peluang sebesar 2,756 kali untuk memiliki risiko tidak berkeinginan untuk tetap bekerja dibandingkan dengan staf rumah sakit yang merasa puas.

\section{PEMBAHASAN}

\section{Gambaran Retensi Staf Rumah Sakit di Provinsi Sulawesi Barat Tahun 2017}

\begin{tabular}{lcc}
$\begin{array}{l}\text { Ada keinginan tetap } \\
\text { bekerja }\end{array}$ & 208 & 85,2 \\
\hline Total & 244 & 100 \\
\hline
\end{tabular}

Tabel 2 menunjukkan bahwa proporsi staf rumah sakit yang memiliki keinginan untuk tetap bekerja $(85,2 \%)$ lebih besar dibandingkan staf rumah sakit yang tidak memiliki keinginan untuk tetap bekerja $(14,8 \%)$. 
Berdasarkan data Statistik PLN 2014, Provinsi Sulawesi Barat pada tahun 2014 memiliki rasio elektrifikasi sebesar 52,69\%. Hal ini lebih rendah jika dibandingkan secara nasional yang sebesar $81,70 \%$ (PT PLN (Persero), 2015). Rasio elektrifikasi yang dimaksud adalah perbandingan jumlah rumah tangga yang berlistrik dan jumlah keseluruhan rumah tangga (PT PLN (Persero), 2014). Rendahnya rasio elektrifikasi pada Provinsi Sulawesi Barat ini disebabkan oleh luas wilayah dan jarak antar rumah tangga cukup jauh (Kementerian PPN/Bappenas, 2015). Dengan demikian, meskipun dengan rendahnya rasio elektrifikasi di Provinsi Sulawesi Barat, namun ketersediaan listrik di seluruh rumah sakit di Provinsi Sulawesi Barat tetap tersedia. Hal inilah yang dapat menjadi alasan kuat staf rumah sakit untuk betah bertugas sehingga mendasari mereka berkeinginan untuk tetap bekerja.

Menurut Komite Medik RSUD Regional Sulawesi Barat yang dikutip dalam laman berita Wacana.info yang dituis oleh Harmay (2017), dengan terbatasnya ketersediaan fasilitas penunjang kerja, maka tenaga kesehatan juga terbatas dalam memberikan pelayanan. Hal ini yang dapat membuat menurunnya kepuasan kerja tenaga kesehatan di rumah sakit sehingga mereka bisa mogok kerja atau bahkan memilih pindah atau keluar dari rumah sakit tersebut.

Niat mengabdi yang dimiliki staf rumah sakit merupakan salah satu bentuk tingkah perilaku masyarakat Provinsi Sulawesi Barat sebagai wujud dari nilainilai budaya mandar yang mengajarkan nilai passemandaran serta nilai kebijakan dan nilai kemandaran diajarkan berdasarkan sejarah sehingga membentuk persepsi yang memiliki visi yang sama dengan Pancasila (Alimin, 2018). Selain itu juga, niat mengabdi merefleksikan etos kerja yang dimiliki staf rumah sakit sangat besar. Kehidupan laut mengajarkan masyarakat Sulawesi Barat bahwa etos kerja sebagai sesuatu yang positif, amat luhur dan murni, kebudayaan para leluhur, bentuk ibadah kepada Tuhan Yang Maha Esa, serta pertanggung jawaban kepada keluarga (Amrullah \& Syukur, 2018).

Namun, meskipun hasil penelitian menunjukkan bahwa sebagian besar staf rumah sakit yang berkeinginan untuk tetap bekerja terdapat pula beberapa staf rumah sakit yang tidak berkeinginan untuk tetap bekerja. Berdasarkan data Risnakes 2017, dapat diketahui pula alasan tidak betah bertugas terbesar yang mendasari staf rumah sakit sehingga mereka tidak berkeinginan untuk tetap bekerja yaitu jauh dari keluarga, bukan daerah asal (kampung halaman) sendiri atau pasangan, dan penghasilan kurang.

Penghasilan menjadi faktor penting seorang karyawan dalam memutuskan apakah bertahan pada suatu perusahaan atau tidak. Apabila penghasilan yang diterima seorang karyawan tidak sepadan dengan pekerjaannya dan/atau tidak dapat memenuhi kebutuhan sehari-harinya maka akan membuat karyawan mencari alternatif pekerjaan lain dan cenderung berkeinginan untuk keluar dari pekerjannya.

Tingkat retensi karyawan yang tinggi berdampak positif bagi perusahaan apabila pihak perusahaan sangat memperhatikan faktor-faktor penting yang berpengaruh terhadap retensi karyawan (Putra \& Rahyuda, 2016). Tingkat retensi seorang karyawan yang tinggi dapat mempengaruhi kinerja perusahaan dalam mencapai tujuannya (Fatima, 2011). Selain itu, retensi karyawan (employee retention) erat kaitannya dengan turnover intention (Adzka \& Perdhana, 2017).

Perputaran karyawan pada tenaga kerja kesehatan merupakan suatu hal yang memang perlu untuk menjadi perhatian bagi para stakeholder di institusi pelayanan. Hal ini dikarenakan pergantian karyawan membutuhkan biaya yang tidak sedikit serta dapat berpengaruh kepada kinerja organisasi dan kualitas pelayanan 
(Steinmetz dkk., 2014). Sangat diperlukan perumusan dan penerapan strategi retensi yang kuat untuk mengurangi tingkat turnover secara efektif (Ghosh dkk., 2013). Hal yang terpenting dalam penerapan strategi retensi karyawan adalah menentukan metode yang tepat untuk memicu karyawan merasa puas dan merasa diperhatikan dari berbagai sisi oleh pihak perusahaan (Sa'diyah \& Irawati, 2017).

\section{Hubungan Kepuasan Kerja dengan Retensi Staf Rumah Sakit di Provinsi Sulawesi Barat Tahun 2017}

Hasil penelitian menunjukkan bahwa semakin besar rasa puas yang dimiliki karyawan terhadap pekerjaannya maka keinginan untuk tetap bekerja yang dimiliki karyawan semakin besar. Namun, meskipun persentase staf rumah sakit yang merasa puas dan berkeinginan untuk tetap bekerja lebih besar, disisi lain sebagian besar dari staf rumah sakit yang merasa tidak puas juga berkeinginan untuk tetap bekerja. Keputusan untuk berkeinginan tetap bekerja yang dimiliki karyawan juga tidak terlepas dari terbentuknya sikap, perilaku, dan pemikiran yang dipengaruhi oleh faktor budaya yang dimiliki. Seperti yang sudah dijelaskan di pembahasan retensi sebelumnya, bahwa terdapat alasan betah bertugas yang mendasari staf rumah sakit sehingga mereka berkeinginan untuk tetap bekerja yaitu tersedianya listrik dan niat mengabdi.

Penelitian ini sejalan dengan penelitian yang dilakukan oleh Aprillia \& Mukti (2018) dan Lisdayanti (2015) dimana menunjukkan hasil bahwasanya kepuasan kerja berpengaruh secara positif dan signifikan terhadap retensi karyawan. Dimana apabila terjadi peningkatan pada kepuasan kerja karyawan, maka terjadi peningkatan pula pada retensi karyawan. Karyawan yang puas terhadap pekerjaannya, mereka lebih berdedikasi untuk pertumbuhan perusahaan dimana tempat ia bekerja. Serta apabila karyawan merasa puas dengan pekerjaannya maka mereka akan tetap bertahan dan bekerja untuk perusahaan. Dengan kata lain, apabila karyawan merasa puas dengan pekerjaannya, mereka akan tetap bersama perusahaan (Biason, 2020).

Menyelidiki kemungkinan perubahan dalam sumber ketidakpuasan dari waktu ke waktu didapatkan bahwa faktor-faktor terkait lingkungan kerja masih berperan penting dalam mempengaruhi kepuasan kerja karyawan serta pengambilan keputusan untuk keluar dibandingkan faktor individu atau demografis. Hasil temuan yang tidak konsisten ini menunjukkan bahwa memang sangat penting untuk menilai serta meninjau kembali sumber kepuasan kerja seiring perubahan waktu (Coomber \& Barriball, 2017). Retensi karyawan yang berkompeten menjadi tantangan besar bagi organisasi terutama bagi institusi pelayanan Kesehatan (Aamir dkk., 2016). Oleh karena itu, sebagai upaya meningkatkan retensi staf rumah sakit sangat penting bagi para pemangku kebijakan di seluruh rumah sakit di Provinsi Sulawesi Barat untuk memperhatikan selalu faktor-faktor penting dalam meningkatkan serta mempertahankan kepuasan kerja staf rumah sakit. Hal ini karena, kepuasan kerja dan retensi merupakan dua faktor penting dalam menentukan keberhasilan kinerja seluruh rumah sakit di Provinsi Sulawesi Barat dalam memberikan pelayanan kesehatan kepada masyarakat.

\section{KESIMPULAN}

Kesimpulan penelitian ini adalah sebanyak $51,2 \%$ staf rumah sakit merasa puas terhadap pekerjaannya dan sebanyak $85,2 \%$ staf rumah sakit berkeinginan untuk tetap bekerja pada rumah sakit yang sama. Hasil uji bivariat menunjukkan adanya hubungan antara kepuasan kerja dengan retensi staf rumah sakit di Provinsi Sulawesi Barat Tahun 2017, hal ini berarti semakin besar rasa puas yang dimiliki karyawan 
terhadap pekerjaannya maka keinginan untuk tetap bekerja yang dimiliki karyawan semakin besar

\section{SARAN}

Seluruh rumah sakit di Provinsi Sulawesi Barat sebaiknya melakukan peningkatan terhadap manajemen SDM melalui peningkatan kegiatan monitoring dan evaluasi, dilakukannya peninjauan secara berkala pada faktor-faktor kepuasan kerja seiring berjalannya waktu, memperhatikan faktor retensi, dan menjadikan penelitian-penelitian mengenai kepuasan kerja dan retensi sebagai referensi dalam menerapkan strategi untuk meningkatkan kepuasan kerja dan retensi.

\section{DAFTAR PUSTAKA}

Aamir, A., Hamid, A. B. A., Haider, M., \& Akhtar, C. S. (2016). Work-life balance, job satisfaction and nurses retention: Moderating role of work volition. International Journal of Business Excellence, 10(4), 488501.

https://doi.org/10.1504/IJBEX.2016 .079257

Aditeresna, K. A. R., \& Mujiati, N. W. (2018). Pengaruh Kompensasi, Kepuasan Kerja Dan Pengembangan Karir Terhadap Retensi Karyawan Di Kutabex Hotel. E-Jurnal Manajemen Universitas Udayana, 7(11), 58145845.

https://doi.org/10.24843/EJMUNU D.2018.v07.i11.p01

Adzka, S. A., \& Perdhana, M. S. (2017). Analisis Faktor Yang Mempengaruhi Retensi Karyawan. Diponegoro Journal Of Management, 6(4), 1-7.

Alimin, A. A. (2018). Budaya Mandar sebagai akar dari Pancasila. https://nusantararesearch.com/2018/ 06/budaya-mandar-sebagai-akardari-pancasila/

Amrullah, F., \& Syukur, M. (2018). Etos Kerja Nelayan Masyarakat Pesisir Di Somba Kelurahan Mosso Kecamatan Sendana Kabupaten Majene Sulawesi Barat. 27-32.

Aprillia, F., \& Mukti, A. H. (2018). Pengaruh Lingkungan Kerja dan Perceived Organization Support (Pos) Terhadap Kepuasan Kerja dan Dampaknya Terhadap Retensi Karyawan. Jurnal Ilmiah Bisnis, Pasar Modal, dan UMKM, 1(1), 1926.

Badan Penelitian dan Pengembangan Kesehatan. (2017). Laporan Riset Ketenagaan di Bidang Kesehatan (Risnakes) 2017: Rumah Sakit. Kementerian Kesehatan RI.

Biason, R. S. (2020). The Effect Of Job Satisfaction On Employee Retention. International Journal of Economics, Commerce and Management, 8(3), 405-413.

Coomber, B., \& Barriball, K. L. (2017). Impact of job satisfaction components on intent to leave and turnover for hospital-based nurses: A review of the research literature. International Journal of Nursing Studies, 44(2), 297-314. https://doi.org/10.1016/j.ijnurstu.20 06.02 .004

Fatima, H. (2011). Does Employee retention affect Organizational Competence? Journal of Industrial Engineering Letters, 1(1), 24-40.

Ghosh, P., Satyawadi, R., Prasad Joshi, J., \& Shadman, Mohd. (2013). Who stays with you? Factors predicting employees' intention to stay. International Journal of Organizational Analysis, 21(3), 288-312.

https://doi.org/10.1108/IJOA-Sep2011-0511 
Harmay, M. (2017, Oktober). Tenaga Kesehatan di RSUD Regional Sulbar Rame-Reme Mogok, Ini Alasannya.

http://wacana.info/berita/2083/tena ga-kesehatan-di-rsud-regionalsulbar-ramereme-mogok-inialasannya

Hilda, Maidin, A., \& Sudirman, I. (2014). Hubungan Gaya Kepemimpinan, Budaya Organisasi Dan Imbalan Dengan Kepuasan Kerja Dan Kinerja Perawat Pelaksana. Jurnal Sains dan Teknologi, 4, 155-165.

Iqbal, S., Ehsan, S., Rizwan, M., \& Noreen, M. (2014). The impact of organizational commitment, job satisfaction, job stress and leadership support on turnover intention in educational institutes. International Journal of Human Resource Studies, 4(2), 181-195. https://doi.org/10.5296/ijhrs.v4i2.5 906

Karthi, D. R., \& Devi, P. J. (2012). A Study On Employee Retention In Leading Multinational Automobile Sector In India. International Journal of Management Research And Review, 2(9), 1474-1482.

Kementerian PPN/Bappenas. (2015). Seri Analisis Pembangunan Wilayah Provinsi Sulawesi Barat 2015Bappe. SIMREG Bappenas. https://simreg.bappenas.go.id/assets /temaalus/document/Publikasi/Dok Pub/Analisis\%20Provinsi\%20Sula wesi\%20Barat $\% 20 \% 202015$ ok.pd $\mathrm{f}$

Lisdayanti. (2015). Pengaruh Kepuasan Kerja Terhadap Retensi Karyawan Pada Pt Bumi Sari Prima Pematangsiantar. Jurnal MAKER, 1(1), 30-38.

Martoyo, S. (2007). Manajemen Sumber Daya Manusia (5 ed.). BPFE.

Novitasari, N. (2019). Pengaruh Motivasi dan Kepuasan Kerja Terhadap
Kinerja Perawat Rumah Sakit Putera Bahagia Cirebon. Jurnal Ilmiah Universitas Batanghari Jambi, 19(1), 179-182. https://doi.org/10.33087/jiubj.v19i1 .588

Prayoga, D., Lailiyah, S., \& Eka Sari, J. D. (2017). Analisis Kepuasan Karyawan Dan Akreditasi Rumah Sakit Umum Daerah Blambangan Kabupaten Banyuwangi. Jurnal Riset Akuntansi Dan Bisnis Airlangga, 2(2). https://doi.org/10.31093/jraba.v2i2. 45

PT PLN (Persero). (2014). Rencana Usaha Penyediaan Tenaga Listrik PT PLN (Persero) 2015-2024. PT PLN (Persero).

PT PLN (Persero). (2015). Statistik PLN 2014. Sekretariat Perusahaan PT PLN (Persero).

Putra, I. B. G. S., \& Rahyuda, A. G. (2016). Pengaruh Kompensasi, Lingkungan Kerja Dan Perceived Organizational Support (Pos) Terhadap Retensi Karyawan. E-Jurnal Manajemen Unud, 5(2), 810-837.

Robbins, S. P., \& Judge, T. A. (2011). Organizational Behavior (Fourteenth Edition). Pearson.

Sa'diyah, H., \& Irawati, S. A. (2017). Pengaruh Employee Retention Dan Turnover Intention Terhadap Kinerja Karyawan Melalui Kepuasan Kerja Pada Kospin Jasa Cabang Jawa Timur. Jurnal Universitas Trunojoyo Madura, 11(1), 34-65.

Steinmetz, S., Vries, D. H. de, \& Tijdens, K. G. (2014). Should I stay or should I go? The impact of working time and wages on retention in the health workforce. Human Resources for Health, 12(1), 12. https://doi.org/10.1186/1478-449112-23 
Sumarni, M. (2011). Pengaruh Employee Retention Terhadap Turnover Intention dan Kinerja Karyawan. Jurnal Akmenika UPY, 8, 20-47.

Susilo, A. (2013). Pengaruh Retensi Karyawan dan Kepuasan Pelanggan Terhadap Kinerja. Jurnal Studia
Akuntansi dan Bisnis, 1(3), 247262.

Undang-Undang Republik Indonesia Nomor 44 Tahun 2009. (2009). Undang-Undang Republik Indonesia Nomor 44 Tahun 2009 Tentang Rumah Sakit. 